\title{
REPRODUCTIVE BEHAVIOR OF ARUNDO DONAX L.
}

\author{
C. A. Nikhade ${ }^{1}$ and K. H. Makde ${ }^{2}$ \\ 1 Chintamani Arts \& Science College, Gondpipri(M.S.), India. 2 \\ Botany and Head, RTM Nagpur University, Nagpur(M.S.), India.
}

\begin{abstract}
:
The paper deals with the reproductive investigations of Arundo donax L. The anther wall development conforms to the Monocot type. Male sterility is related to the abnormal behavior of tapetum. The ovules are bitegmic, campylotropous, tenuicellate, feeble tendency towards pseudo-crassi nucellate. Polygonum types of embryo sac with antipodal complex are noticed. The degenerating zygote has been noticed in the embryo sac indicating that after fertilization further development of the embryo are restricted. Hence seeds are abortive. It mostly reproduces vegetatively by underground rhizomes.
\end{abstract}

\section{Keywords:}

Poaceae, Pooideae, Male and Female Gametophyte, Sterility, Antipodal Complex, Hypostase, Abortive seed, Vegetative reproduction.

\section{Introduction:}

The division of Poaceae into two sub-families viz., Pooideae \& Panicoideae as produced by Brown (1814) is being maintained even today. Embryological features of this taxon follow the uniform pattern at sub-family level (Narayanswami, 1952, 1953; Koul, 1970 a, b; Bhanwra et.al., 1991; Deshpande \& Makde 1994; Nikhade \& Makde, 1997). The present paper pointed out some defective embryological characters.

\section{Materials And Method :}

The material of Arundo donax was collected from Maharajbagh locality of Nagpur (M.S.), India. The voucher specimens submitted to the herbarium of Botany Department, RTM Nagpur University. Spikelets at various stages of development were fixed in 70\% F.A.A. The customary methods of dehydration, infiltration and embedding followed. Sections were cut $8-10 \mu$ thick \& stained with Delafield hematoxylin. Erythrosin and light green stain was used as 
counter stain. The sections were mounted in Canada balsam. Diagrams were drawn with the help of camera lucida.

\section{Microsporogenesis And Male Gametophyte :}

The anthers are bithecous and tetralocular. It has a column of sterile tissue in the centre, called as connective (Fig. 1A). A very young anther consists of a homogenous mass of cells bound by a single layer epidermis. The male archesporium develops hypodermally and consist of single row of cells (Fig. 1B). The archesporial cells divide periclinally cutting of primary parietal cells outward and primary sporogenous cells inwards. The cells of the parietal layer undergo a series of periclinal and anticlinal divisions to form concentric layers of anther wall. The primary sporogenous cells, after a few mitosis, function as microspore mother cells. The cells of the inner secondary parietal layer, again divide periclinally to form a single middle layer on the outside and the tapetum towards the inner side that surrounds the central sporogenous mass. Thus, the development of anther wall conforms to Monocotyledonous type (Davis, 1966).

The epidermal cells are more or less rectangular in young condition. At maturity the epidermal cells greatly stretched and an irregularly shaped. The outer tangential wall shows echinate outgrowth. These projections are probably siliceous in nature and protective functions. The tannin granules of varied shapes found in epidermal cells (Fig. 1F).

The endothecium originates from the parietal layer. The endodermal cells are radially elongated and attain its maximum development when anther is ready to dehisce. The finger like fibrous bands are observed on the inner tangential walls, they extend outward and upward terminating near the outer tangential wall. These bands are distinctly -VII or -Ull shaped (Fig. 1G). In some mature anther the endothecial layer get disintegrated all over the inner surface except near the stomium (Fig. 1H). 
The fibrous bands are not developed in the endothecial cells of sterile anthers (Fig. 1D). Distinct _Ubisch' granules are noticed on the inner tangential walls of endothecium.

The middle layers are ephemeral and crushed during the meiosis in pollen mother cells. However, degenerated remains of the middle layer are observed during meiosis I and II (Fig. 1E).

The tapetum is the inner most layer that completely surrounds the central sporogenous tissue. In Arundo donax, the tapetum originates solely from the parietal layer and remains uninucleate throughout the anther development.

The primary sporogenous cells divide mitotically, thereby increases in the number of microspore mother cells. As seen in transverse section the numbers of rows of microspore mother cells are 2-6 in an anther lobe (Fig. 1C). The pollen mother cells are very prominent and appear polygonal in shape. The cells are densely cytoplasmic with a conspicuous centrally located nucleus.

Meiotic divisions are normal. At close of meiosis I, wall is laid which results in dyads. In meiosis II, both dyad cells are accompanied by septum formation hence cytokinesis is of successive type (Fig. 1E). The resultant microspore tetrads are isobilateral type.

The young microspore is spherical, richly cytoplasmic with a centrally located nucleus. Soon after its release from the tetrad then the microspore called as Pollen grain (Fig. 1I). The uninucleate pollen grains contain granular cytoplasm with well developed exine and intine. The first mitotic division of the pollen grains results in smaller generative cell and larger vegetative cell. The two nuclei lie side by side and cytoplasm becomes alveolar in which few starch grains are deposited (Fig. 1J). The smaller generative cell lies freely in the cytoplasm, which under goes mitosis and produces two sperms or male gametes (Fig. 1K). The mature pollen grains released through the stomium at 2-celled or 3-celled stage. The degenerating pollen mother cells and pollen grains are noticed in many anthers. 


\section{OVULE, MEGASPOROGENESIS AND EMBRYO SAC:}

The Poaceae is characterized by bi/tricarpellary, syncarpous pistil having a single ovule in the unilocular ovary. The ovule is attached on a short funiculus at or near the base of the ovary wall (Fig. 2E).

The megasporangium together with its protective coats the integuments is called ovule. The ovule is bitegmic and both the integuments inner and outer are two layered for their major portion. These integuments near the tip of micropyle become three layered thick. The micropyle is generally organized by the inner integuments is called endostome (Fig. 3D).

A single hypodermal cell in the nucellus functions as the archesporium (Fig. 2A). It directly functions as megaspore mother cell. Therefore, the ovule is tenuinucellate in the plant (Fig. 2F). More than one archesporium are noticed but only one of them is functional (Fig. 2G, I). Megaspore mother cell, also called megasporocyte, undergoes meiosis to from four haploid megaspores. After the first meiotic division wall is laid down transversely forming a dyad (Fig. 2H). Similarly, the second division in the two dyad cells is synchronous. This division is followed by transverse wall formation. In this taxon cytokinesis after second meiotic division is delayed considerably (Fig. 2I). The megaspore tetrads are mostly linear. Twin linear tetrads of megaspores have been reported out of which one tetrad undergoes degeneration (Fig. 2G, I). Three micropylar megaspore degenerates. The functional chalazal megaspore provided with dense cytoplasm and centrally situated nucleus enlarges considerably during development. Its nucleus undergoes three successive mitotic divisions to produce eight nuclei. Then cellular organization of the embryo sac starts. At the micropylar end of the embryo sac three nuclei organize into egg apparatus and fourth one as a polar nucleus.

The chalazal 3 nuclei develop into an antipodals and fourth migrate in the centre as a polar. The synergids of the egg apparatus is attached to the embryo sac. Their hooks are pointed out wards. A filiform apparatus is present at the micropylar end of each synergid (Fig. 3C). Synergids are ephemeral structures 
and degenerates immediately after the embryo sac has received the pollen tube discharge (Fig. 3G). The degenerating zygotes have been noticed in the embryo sac indicating that after fertilization further development of the embryo are restricted.

Antipodals and Antipodal complex: At the time of organization of embryo sac there are only three antipodal cells located at the chalazal end. Mitotic divisions in them result in an increase in their number, these constituting the antipodal complex at the chalazal end (Fig. 3E).

Hypostase: A group of cells present below the embryo sac and above the vascular supply to the funiculus. It is cup shaped and well developed. A tannin deposition starts in this region very fast. Thus, hypostase here may acts as a barrier for the vascular supply between the funiculus and embryo sac and causes the abortive ovule in this taxon (Fig. 3F, H).

Pericarp and Seed coat: The young ovary wall is made up of a variable number of parenchyma layers. The number of layers of ovary wall remains constant up to dyad and tetrad stage respectively. At mature embryo sac stage these layers increase up to 9 layers but this increase is restricted to middle part of the ovule. At zygote stage the silica granule are found to be deposited in the outer epidermis of Pericarp (Fig. 3F, H). The ovules are bitegmic but an outer integument degenerates after fertilization (Fig. 3F). Both the layer of inner integument persists in the abortive seed. The pericarp remains free from the seed coat (Abortive seed).

\section{DISCUSSION:}

The members of Poaceae differ from all other families particularly in the characters of inflorescence, embryo, seeds and fruits.

The division of Poaceae into two sub-families viz; Pooideae and Panicoideae as proposed by Brown (1814) is being maintained even today.

The present embryological work on Arundo donax belongs to sub-family Pooideae. The anther wall is four layered and its development typically 
conforms to the monocotyledonous type of Davis (1966). The outer tangential walls of epidermis has an echinate appearance, a feature reported earlier by Batygina (1974, 1978), Diwanji (1976), Hari Gopal and Manasi Ram (1981).

In the hypodermal endothecium develops fibrous thickenings in most members of Poaceae (Narayanswami, 1952, 1953; Untawale et al. 1969; Gawali, 1977; Raju 1980; Bhandari and Khosla 1982; Bhanwra 1985, 1988; Ghaisas 1991). The fibrous bands are not developed in the endothecial cells of sterile anthers. The single middle layer is ephemeral and become completely crushed at dyad and microspore tetrad stage (Swamy and Krishnamurthy 1980).

The tapetum comprises a uninucleate, single layer and originates from parietal tissue and is not of dual origin. The present investigation strongly supports the contention put forth by Bhandari and Khosla (1982). The persistent tapetum and abnormality in endothecium is investigated in this taxon which leads for pollen sterility.

The sporogenous cells are less in number which speaks to low output of pollen grains.

It has been pointed out that male sterility is related to the abnormal behavior of tapetum supports the observation of Zenkteler (1962), Chauhan and Singh (1966).

The ovule in its form is campylotropous. The archesporial cell enlarges and functions as megaspore mother cell. Thus parietal cell or tissue is not formed in the ovule. According to Davis (1966), this condition is found in taxon belonging to Pooideae, while in Panicoideae nucellar epidermis at the tip in the micropylar region divides periclinally and forms a cap of variable number of layers. However, a feeble tendency towards pseudo-crassinucellate is reported in the present investigation. The megaspore tetrads of varying pattern either TShaped or Linear. Twin linear tetrads have been reported by Muniyamma, 1969; Ghaisas, 1991 which is also corroborated by the present work. A small nucellar beak develops from the nucellar epidermis. The chalazal megaspore gives rise to embryo sac. The contention that the embryo sac in all sexually 
reproducing members of Poaceae, develops after Polygonum type (Maheshwari, 1950). This is a very constant feature in the family investigated so far (Anderson, 1933; Snyder, 1957; Venkateswarlu and Devi, 1964; Bhanwra, 1988; Febulaus and Pullaiah, 1990, 1992). A tendency towards multiplication of antipodal tissues noticed in the Gramineae (Hector, 1936). The antipodal complex consisting of variable number of cells has been reported by Cannon (1990), Koul (1959), Bennett et. al., (1973), Johri and Ambegaonkar (1975),

Diwanji and Padhye (1977), Bhuskute (1990), Febulaus and Pullaiah (1992), Nikhade and Makde (1997).

In Arundo donax, Bhanwra et. al., (1982) reported the degeneration of megaspore mother cell responsible for sterility. The present study has revealed that degeneration initiate at various stages in the development of mature embryo sac. The nucellar cells at the chalazal end develop distinct hypostase in which the deposition of tannin starts after the fertilization. Thus Sterility begins after the fertilization.

It reproduces vegetatively by underground rhizome naturally. The rhizomes are tough and fibrous, expands deep into the soil (Alden et.al., 1998; Mackenzie, 2004).

\section{REFERENCES:}

Ambegaonkar, K.B. \& B.M. Johri. 1977. Seed development in Triticale -1 . Phytomorph., $27: 190-197$.

Anderson, A.M. 1927. Development of the Female gametophyte and Caryopsis in Poa pratensis and Poa compressa. J. Agric. Res., $\underline{34}$ : $1001-1018$.

*Batygina, T.B. 1974. Wheat Embryology —Kolosll Leningrad(In Russian).

Batygina T.B. 1978. Embryology of wheat Proc. Indian Natl. Sci. Acad. Part B $\underline{44}: 13-29$. 
Bennett, M.D., M.K. RaO, J.B. Smith \& M.W. Bayliss. 1973. Cell development in the anther, the ovule and the young seed of Triticum aestivum L. Var. Chinees Spring. Phil. Trans. Rov.Soc., $\underline{266}$ : 39-81.

Bhanwra, R.K., S. P. Choda \& Kumar, S. (1982) Proc. Indian Nal. Sci. Acad, B $\underline{48}: 152$.

Bhanwra, R.K. 1985. Embryological studies in five species of Eragrostis Beauv. (Gramineae) Res. Bull.(Sci) of Punjab Univ, ed. 37, (Parts - I- II): 17-23.

Bhanwra, R.K. 1988. Embryology in relation to Systematics of Gramineae. Annals of Botany, $\underline{62}: 225-233$.

Bhandari, N.N. \& R. Khosla. 1982. Development and histochemistry of anther in Triticale CV. TRI. I. Some new aspects in early ontogeny. Phytomorphology, $\underline{32}: 18-27$.

Bhuskute, Sushma M. 1990. In Vitro studies on Dendrocalamus strictus Nees and Bambusa arundinacea Moon. with some observations on their embryology and histochemistry. Ph.D. Thesis, Nagpur University, Nagpur.

*Brown, R. 1814. General remarks, geographical and systematical, on the botany of Terra Australis, $\mathrm{Pb} 533-613$ in M. Flinders. A voyage to Terra Australis. Vol 2 London.

Cannon, W.A. 1900. A morphological study of the flower and embryo of the wild oat, Avena fatua.L. Proc, Calif. Acad. Sci., III $\underline{1}$ : 329 - 356.

Chauhan, S.V.S. \& S.P.Singh 1966. Pollen abortion in male sterile haploid wheat (Norin) having Aegilops ovate L. Cytoplasm. Crop. Sci., $\underline{6}$ : 532 535.

Davis, G.L. 1966. Systematic Embryology of the Angiosperms. Wiley, New York.

Deshpande, P.K. 1976. Development of embryo and endosperm in Eragrostis unioloides (Poaceae) Plant syst. Evol. 125 : 253 - 259. 
Deshpande, P.K. \& K.H. Makde, 1994. Embryo and fruit in the Poaceae. Advances in Plant Reproductive Biology Vol. 1 Eds. Chauhan and Pandey. Narendra Publishing House, Delhi.

Diwanji, V.B. 1976. -Embryologicalstudies in Gramineaell. Ph.D. Thesis, University of Indore, Indore.

Diwanji \& Padhye. 1977. The life history of Eragrostis tenuifolia Hochst-ex Steud. In recent Trends and Contacts between Cytogenetics, Embryology and Morphology (Ed.) Dnyansagar, V.R. et. al., 261-276.

Febulaus, G.N.V. \& T. Pullaiah. 1990. Embryology of Chloris roxburghiana Schult (Poaceae). J. Indian bot. Soc. Vol., $\underline{69}: 53-53$.

Febulaus, G.N.V. \& T. Pullaiah. 1992. Embryology of Aristida(Poaceae) J. Indian bot. Soc. Vol. $\underline{71}: 42$.

Johri, B.M. and K. B. Ambegaonkar. 1975. The antipodals in Triticales. Phytomorphology $25: 211-217$.

Gawali, S.P. 1977. Embryological studies in the Gramineae. Ph.D. Thesis, Nagpur University, Nagpur.

Gerenday, A. \& J. French, 1988. Endothecial thickening in anther of Porate Monocotyledons. Amer. J. bot., $\underline{75}$ (1) : $22-25$.

Ghaisas, V. A. 1991. Morphological and Histochemical Investigations on some oil yielding Grasses. Ph.D. Thesis. Nagpur University, Nagpur.

Hari Gopal \& Manasi Ram. 1981. Floral morphology, development of sporangia and sporogenesis in Dendrocalamus hamiltonii. Proc. India Natn, Sci. Acad. $\underline{47}: 519-526$.

Hector, J.M. 1936. Introduction to the Botany of Field Crops. Vol. I. South African Agric. Series. Vol. $\underline{16}$.

Koul, A.K. 1959. Antipodals during the development of caryopsis in Euchlaena Mexicana. Agra Univ. J. Res. (Sci.) $\underline{8}:$ 31-33. 
Maheshwari, P. 1950. An Introduction to the Embryology of Angiosperms. Mc Graw Hill. New York.

Muniyamma, M. 1978. Variationsin microsporogenesis and the development of embryo sacs in Echinochloa stagnina (Rets) P. Beauv(Gramineae) Bot. Gaz., 139 : $87-94$.

Narayanswami, S. 1952. Microsporogenesis and male gametophyte in Eleusine coracana Gaertn. Curr. Sci., 21 : 1921.

Narayanswami, S. 1953. The structure and development of caryopsis in some Indian Millets. I. Pennisetum typhoideum Rich. Phytomorph., $\underline{3}: 288-$ 299.

Raju, P.S.G. 1980. Embryological and Histochemical studies of some crop plants (Gramineae). Ph.D. Thesis. Nagpur University, Nagpur.

Swamy, B.G. \& K.V. Krishnamurthy. 1980. From Flower to Fruit Tata McGraw Hill, New Delhi.

Untawale, A.G., P.K. Deshpande \& K.B. Sharma. 1969. Studies in the gramineae I. Male and Female Gametophytes of Eragrostis unioloides (Retz) Nees. ex steuds. J. Indian Bot. Soc., $\underline{48}: 386$ - 392.

Venkateshwarlu. J \& P.I. Devi. 1964. Embryology of some Indian grasses. Curr. Sci., $\underline{33}: 104$ - 106.

Snyder, L.A. 1957. Apomixis in Paspalum secans. Hitche \& Chase. Amer. J. Bot. $\underline{44}: 318-324$.

Zenkteler, M. 1962. Microsporogenesis and tapetal development in normal and male sterile carrots (Daucus carota); Am. J. Bot., $\underline{49}$ : $341-348$.

*Alden et.al., 1988; Mackenzie, 2004. From Wikipedia, the free encyclopedia. * Not seen original 